DOI:10.17951/h.2020.54.2.77-87

\begin{tabular}{lcc}
\hline & A N N A L E S \\
UNIVERSITATIS MARIAE CURIE-SKŁODOWSKA \\
LUBLIN - POLONIA \\
SOL. LIV, 2
\end{tabular}

\author{
ANNA PLUSKOTA \\ anna.pluskota@uni.lodz.pl \\ University of Lodz. Faculty of Economics and Sociology \\ 3/5 Polskiej Organizacji Wojskowej St., 90-255 Lodz \\ ORCID ID: https://orcid.org/0000-0002-2566-3420
}

\title{
The Impact of Corruption on Economic Growth and Innovation in an Economy in Developed European Countries
}

Keywords: economic growth; innovation; corruption

JEL: D73

How to quote this paper: Pluskota, A. (2020). The Impact of Corruption on Economic Growth and Innovation in an Economy in Developed European Countries. Annales Universitatis Mariae Curie-Sktodowska, sectio H-Oeconomia, Vol. 54, No. 2.

\footnotetext{
Abstract

Theoretical background: The article explores the relationship between corruption and innovation in an economy and between corruption and economic growth. The multi-faceted and complex nature of corruption means that the impact of corruption on innovation and economic growth is unidirectional. There are arguments in the literature for both positive and negative effects of corruption on macroeconomic figures. Most empirical research confirms the linear negative impact of corruption on economic growth. These results are the opposite of theoretical arguments that there may be both positive and negative consequences of corruption.

Purpose of the article: The research aim is to analyse the theoretical aspects of the impact of corruption on selected macroeconomic variables. This goal was achieved by analysing the most significant arguments describing the relationships between chosen variables. Based on the literature analysis, research hypotheses were developed, and they were verified in an empirical study. The results were analysed in the discussion section. Research methods: The study is based on a set of data on economically developed countries in Europe from 1996 to 2017. The empirical study was conducted using basic statistical measures - descriptive statistics and correlation coefficient, whereas econometric models were based on the GMM system (Generalized Method of Moments).
} 


\begin{abstract}
Main findings: The results of this research show that the relationships between corruption and the measure of innovation, and corruption and economic growth are not linear. They take the form of a parabola. This means that the influence of corruption on innovation and economic growth is not the same for all levels of the corruption indicator. The relationship between corruption and economic growth is specific enough to show that a low level of corruption is economically justified from the point of view of empirical research. This is possible because corruption solves other economic problems, such as bureaucracy, which limits development. Corruption will support economic growth if the state does not work properly.
\end{abstract}

\title{
Introduction
}

Corruption is defined as the use of a public position for a private purpose (Pope, 1999, p. 34). This phenomenon, however, is much more complicated and complex, and it affects many areas of human life, not just public life as Pope points out. The multi-faceted and complex nature of corruption means that, despite considerable research on this subject, the impact of corruption on economic figures is still not thoroughly analysed. There are still two separate approaches to the impact of corruption on an economy in the literature. They are illustrated by the wheel of economic growth, where corruption may be the "grease" or "sand" for this wheel (Méon \& Sekkat, 2005). This concept shows that corruption may have a positive or negative impact on economic growth, and it takes into consideration only the economic aspects of this phenomenon, ignoring ethical arguments. In this study, the possibility that both positive and negative effects of corruption occur simultaneously in an economy is analysed. Thus, it contributes to creating a new thread in the debate on the impact of corruption on the economic situation in a country.

The purpose of this paper is to consider the theoretical aspects of the impact of corruption on two important macroeconomic variables, economic growth and innovation in an economy. Economic growth was chosen because of the importance of this measure for assessing the condition of an economy, while the innovativeness of an economy strongly affects the economic situation in a country. The intermediate aim is to verify the research hypotheses based on literature analysis using econometric tools. Research in this area was carried out by, among others, Anokhin and Schulze (2009) and Méndez and Sepúlveda (2006), as noted in the following analysis.

The work comprises a theoretical part, which presents the most important issues concerning the relationship between corruption and economic growth and between corruption and innovation. Then two research hypotheses are developed, and they are then verified in the empirical part of this paper. The results are discussed and then summarised in the conclusion section. The study is based on a set of data on economically developed countries in Europe between 1996 and 2017, on which econometric analyses were conducted using the GMM system (Generalized Method of Moments). Using that model as the base of economically developed countries to analyse the relationship between corruption and macroeconomic variables is an original solution against the background of existing literature. 
That research suggests that, in terms of innovation, an economy should seek to eliminate corruption, which is a common conclusion in the literature. However, research on the relationship between corruption and economic growth showed that the highest economic growth does not occur with zero corruption but at a low level of corruption. In light of the quantitative research, this means that a certain low level of corruption might be justified from the perspective of economic growth.

\section{Literature review}

Most frequently in the literature, there are arguments for the negative impact of corruption on an economy, which is confirmed by most empirical studies based on different econometric models (linear and non-linear). Ahmad, Ullah, and Arfeen (2012, p. 278) noticed that the negative impact of corruption on economic growth was classified as particularly important by such institutions as the World Bank, which recognised "corruption as one of the major impediment to economic and social development" and the International Monetary Fund, which, in contrast, pointed out that "mismanagement [of economic policy - A.P.] clearly harms economic activity and prosperity".

There are two main channels of the negative impact of corruption on an economy, the first concerns the impact of corruption on material resources, and the second relates to the impact of corruption on human capital. The main argument for the negative impact of corruption on an economy is the additional costs of doing business (O'Toole \& Tarp, 2014, p. 568). These costs usually arise from having to pay a bribe or creating an additional job, which burdens the budget and reduces the company's profitability. Additional costs appear when the company attempts to hide these additional costs in the company's books. For this purpose, it must acquire personnel with specific competencies. At the same time, corruption increases the risk of doing business, because if this crime is disclosed, the entrepreneur is exposed to fines or imprisonment, which would hinder running a business. The additional costs of doing business also lower investors' expectations of a rate of return, and it increases the uncertainty of getting a return. Another consequence of bearing the costs of corruption is the inefficient allocation of resources, because the capital intended to cover bribes could develop the enterprise (Drury, Krieckhaus, \& Lusztig, 2006, p. 123). These costs may apply not only to financial resources but also to the employees' working time devoted to the entire corruption process and its concealment. Both monetary capital and human capital will be less effective because of the impact of corruption on them.

The positive effects of corruption may appear in the case where the impact of corruption damages an economy, for instance, corruption may prevent excessive bureaucracy of the state. Cieślik and Goczek $(2015$, p. 94) accurately described this complicated situation: "in an imperfect world, in which disturbances caused by 
irresponsible economic policy occurred, additional disturbances caused by bribes may be the second-best solution and lead to welfare increase". In such a situation, corruption accelerates economic processes and stimulates economic growth, because the bribe makes it possible to shorten the waiting time for a clerical decision (Mo, 2001, p. 66). From the point of view of cost and income analysis in an enterprise, it may turn out that paying a bribe is beneficial to the company's finances. The cost of corruption might be seen as an expense that may reduce transaction costs (Cuervo-Cazurra, 2016, p. 44). This alternative approach to the costs of corruption occurs when paying a bribe reduces the time needed to get a permit for business activity, so the fixed costs of running a company are decreased. Therefore, the sooner the business activity is started, the sooner the income will be generated.

Innovation is treated as a significant factor of economic growth (Nelson \& Pack, 1999, pp. 416-436). Innovative investments contribute to a dynamic increase in the size and quality of human capital (Pastusiak, 2012, p. 354), and this also indirectly contributes to increasing economic growth. Corruption affects the condition of the entire economy, and thus it also affects its innovation. Shera and others point out that "corruption tends to damage innovation activities" (Shera, Dosti, \& Grabova, 2014, p. 58). The sluggishness of officials who deliberately prolong procedures to get a bribe discourages entrepreneurs from undertaking innovative activities (Lau, Yang, Zhang, \& Leung, 2015, pp. 1550004-2). In a corrupt environment, officials are not trustworthy, which also hinders innovation (Anokhin \& Schulze, 2009, p. 474). Lau and others noticed that companies with advanced technologies transfer their innovations from developed countries to developing countries through foreign direct investment. Corruption may discourage foreign investors from taking action in a country, which also hinders the flow of innovation. The positive impact of corruption on the level of innovation may be found only with imperfections in an economy exhibited, for example, by excessive bureaucracy, which corruption may prevent. That is, corruption may be a remedy for a larger "disease" in an economy.

Arguments in the literature that corruption may have both positive and negative effects on an economy led scientists to analyse whether these effects occur simultaneously in certain situations. This may happen when the fight against corruption begins in a country where the negative effects of corruption and the positive effects of combating it are both apparent. Anokhin and Schulze (2009, pp. 465-476) pointed out that corruption in an economy has an impact that is related to a decrease in the marginal negative effects of corruption together with a decrease in its level.

\section{Research hypotheses, empirical data, and theoretical models}

The simultaneous occurrence of positive and negative effects of corruption on an economy undermines the legitimacy of using a linear function to describe the relationship between corruption and macroeconomic variables. This requires new 
research hypotheses based on a non-linear relationship between measures of corruption and macroeconomic variables.

The research hypotheses based on the literature analysis are:

1) The relationship between corruption and innovation is non-linear and takes the form of a parabola.

2) The relationship between corruption and economic growth is non-linear and takes the form of a parabola.

The relationship between corruption and economic growth and between corruption and innovation has been studied by Anokhin and Schulze (2009, pp. 465-476), Wright and Craigwell (2013, pp. 24-29), and Jain, Kuvvet, and Pagano (2017, pp. 23-35), among others. They used the properties of the square function to verify research hypotheses, whereas Aghion, Akcigit, Cagé, and Kerr (2016, p. 32) selected the properties of the logarithmic function to study the non-linear relationship between corruption and macroeconomic measures.

Because of the difficulties in measuring corruption, an area with very similar cultural and political determinants of corruption was selected for analysis. This empirical study uses the Gross National Product per capita to identify European countries with higher average income and high per capita income (from USD 4,036/person according to the World Bank classification). The above hypotheses were verified on the basis of panel macroeconomic data collected for 24 European countries: Austria, Croatia, the Czech Republic, Denmark, Estonia, Finland, France, Germany, Greece, Hungary, Ireland, Latvia, Lithuania, the Netherlands, Poland, Norway, Portugal, Russia, Slovakia, Slovenia, Spain, Sweden, Switzerland, and the United Kingdom. The relevant time series were downloaded from the World Bank database. Data cover the period from 1996 to 2017 (time series length of 22). The analysis is based on the variables shown in Table 1.

Table 1. Data source

\begin{tabular}{|l|l|l|}
\hline \multicolumn{1}{|c|}{ Variable } & \multicolumn{1}{|c|}{ Source } & \multicolumn{1}{c|}{ Description } \\
\hline Economic growth & World Bank & Economic growth rate. \\
\hline Innovation & World Bank & Number of patent applications. \\
\hline Corruption & World Bank & $\begin{array}{l}\text { Corruption control indicator. It takes a value from 0 to 5, where 0 means } \\
\text { a completely corrupt state, and 5 means a state free from corruption. }\end{array}$ \\
\hline Investments & World Bank & $\begin{array}{l}\text { The contribution of investments to the country's GDP, that is, the invest- } \\
\text { ment rate. }\end{array}$ \\
\hline Population growth & World Bank & The population growth rate of the country. \\
\hline Log(GDP)t-1 & World Bank & Logarithm of Gross Domestic Product per capita. \\
\hline
\end{tabular}

Source: Author's own study.

Research hypothesis No. 1 will be verified using models for innovation in economies from equations 1 to 3 , whereas research hypothesis No. 2 will be verified using models for economic growth from equations 4 to 6 : 


$$
\begin{aligned}
& \text { innovation }_{i, t}=\alpha_{i, t}+\beta_{1} \text { cor }_{i, t}+\beta_{2} \text { cor }_{i, t}^{2}+\beta_{3} \text { economic growt }_{i, t}+u_{i, t} \\
& \text { innovation }_{i, t}=\alpha_{i, t}+\beta_{1} \text { cor }_{i, t}+\beta_{2} \log (\text { corruption })_{i, t}+\beta_{3} \text { economic growt }_{i, t}+u_{i, t} \\
& \text { innovation }_{i, t}=\alpha_{i, t}+\beta_{1} \text { cor }_{i, t}+\beta_{2} \text { economic growt }_{i, t}+u_{i, t} \\
& \text { economic growth } \text { grt }_{i, t}+\beta_{1} \operatorname{cor}_{i, t}+\beta_{2} \operatorname{cor}_{i, t}^{2}+\beta_{3} \log (G D P)_{i, t-1}+
\end{aligned}
$$

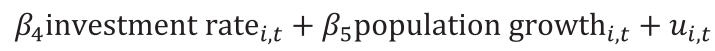

$$
\begin{aligned}
& \text { economic growth } h_{i, t}=\alpha_{i, t}+\beta_{1} \operatorname{cor}_{i, t}+\beta_{2} \log (\text { corruption })_{i, t}+\beta_{3} \log (G D P)_{i, t-1}+ \\
& \beta_{4} \text { investment rate }_{i, t}+\beta_{5} \text { population growth }_{i, t}+u_{i, t} \\
& \text { economic growth } h_{i, t}=\alpha_{i, t}+\beta_{1} \operatorname{cor}_{i, t}+\beta_{2} \log (G D P)_{i, t-1}+\beta_{3} \text { investment rate }_{i, t}+ \\
& \beta_{4} \text { population growth } \text { gr,t }_{i, t}
\end{aligned}
$$

Random error in the above six models may be defined using formula 7, where $\eta$ means random effects on a given country, $\gamma$ means random effects for a given period, and $\varepsilon$ is a random component with basic properties.

$$
u_{i, t}=\eta_{i}+\gamma_{t}+\varepsilon_{i, t}
$$

Corruption is difficult to measure because of its confidentiality. The corruption control indicator published by the World Bank was used in the research. This indicator is based on many data sources, while the results are compared with other measures of corruption. Originally, this measure used values from -2.5 to 2.5 , however, for this study, the corruption index has been scaled to be between 0 and 5 , because some econometric models contain a measure of corruption in a logarithmic form. Negative values of the corruption indicator cannot be transformed into logarithms, hence using the original values of the indicator would significantly reduce the amount of data in the models.

\section{Results}

This section presents the results of statistical and empirical research based on the data from the previous part of the work. The empirical analysis was started by checking the value of descriptive statistics and the correlation coefficient for selected variables. The diversity of participating countries was based on the level of economic growth and the measure of innovation, which is indicated by descriptive statistics. Corruption is poorly correlated with economic growth and a measure of innovation. 
Pobrane z czasopisma Annales H - Oeconomia http://oeconomia.annales.umcs.pl Data: 26/04/2023 11:47:23

THE IMPACT OF CORRUPTION ON ECONOMIC GROWTH AND INNOVATION IN AN ECONOMY...

Table 2. Descriptive statistics and correlation for selected variables

\begin{tabular}{|c|c|c|c|c|c|c|}
\hline & Corruption & $\begin{array}{c}\text { Economic } \\
\text { growth }\end{array}$ & $\log (\mathrm{GDP})$ & Investments & $\begin{array}{l}\text { Population } \\
\text { growth }\end{array}$ & Innovation \\
\hline Average & 3.635 & 2.517 & 4.394 & 4.085 & 0.164 & 5306.642 \\
\hline Median & 3.689 & 2.428 & 4.431 & 3.641 & 0.242 & 1300.000 \\
\hline Maximum & 4.970 & 23.941 & 4.962 & 51.078 & 2.891 & 51736.000 \\
\hline Minimum & 1.368 & -14.560 & 3.711 & -38.903 & -3.848 & 12.000 \\
\hline Standard deviation & 0.896 & 3.730 & 0.314 & 10.163 & 0.688 & 10769.170 \\
\hline \multicolumn{7}{|l|}{ Correlation } \\
\hline & Corruption & $\begin{array}{c}\text { Economic } \\
\text { growth }\end{array}$ & $\log (G D P)$ & Investments & $\begin{array}{c}\text { Population } \\
\text { growth }\end{array}$ & Innovation \\
\hline Corruption & 1.000 & - & - & - & - & - \\
\hline Economic growth & -0.152 & 1.000 & - & - & - & - \\
\hline $\log ($ GDP $)$ & 0.855 & -0.282 & 1.000 & - & - & - \\
\hline Investments & -0.088 & 0.802 & -0.200 & 1.000 & - & - \\
\hline Population growth & 0.526 & -0.257 & 0.672 & -0.147 & 1.000 & - \\
\hline Innovation & 0.041 & -0.089 & 0.089 & -0.085 & 0.021 & 1.000 \\
\hline
\end{tabular}

Source: Author's own study.

The first research hypothesis was verified using equations 1 to 3 . Econometric models were estimated using the GMM system, where the instruments of the model were delayed by one period. Statistics J confirms the correctness of the models in Table 3. The determination coefficient in each of the three models is very high, at $99 \%$. Variables in the model have a statistically significant impact on the explanatory variable. Economic growth has a positive effect on the measure of innovation (a positive factor for the variable of economic growth). The coefficient for corruption in Model 1 is negative, whereas for a corruption rate squared it is positive. This means that the chart of the relationship between corruption and innovation takes the shape of a parabola with arms facing up. In Model 2, the coefficient for corruption is positive and the coefficient for the logarithm of corruption is negative, which also shows the relationship between the variables to be parabola-shaped with their arms facing up. For Model 3, the coefficient standing by the variable of corruption is statistically significant only at the level of 0.10 . Based on this statistic, it might be concluded that models with a non-linear relationship between corruption and the measure of innovation properly describe this relationship. The first research hypothesis was confirmed on the basis of Models 1 and 2.

Table 3. Models for innovation

\begin{tabular}{|c|c|c|c|}
\hline & Model 1 & Model 2 & Model 3 \\
\hline Constant & $\begin{array}{c}13014.70 \\
(* * *)\end{array}$ & $\begin{array}{c}3786.17 \\
(* * *)\end{array}$ & $\begin{array}{c}2626.39 \\
(* *)\end{array}$ \\
\hline Corruption & $\begin{array}{c}-6540.99 \\
(* * *)\end{array}$ & $\begin{array}{c}6246.15 \\
(* * *)\end{array}$ & $\begin{array}{c}602.08 \\
(*)\end{array}$ \\
\hline Corruption^2 & $\begin{array}{c}1110.924 \\
(* * *)\end{array}$ & - & - \\
\hline
\end{tabular}


Pobrane z czasopisma Annales H - Oeconomia http://oeconomia.annales.umcs.pl Data: 26/04/2023 11:47:23

\begin{tabular}{|l|c|c|c|}
\hline & Model 1 & Model 2 & Model 3 \\
\hline $\log ($ Corruption $)$ & - & -17273.46 & - \\
\hline \multirow{2}{*}{ Economic growth } & 210.36 & $(* *)$ & 208.86 \\
\hline $\mathrm{R}^{\wedge} 2$ & $(* *)$ & $(* * *)$ & $(* * *)$ \\
\hline Statistics J & 0.9907 & 0.9907 & 0.9905 \\
\hline
\end{tabular}

Note: $p$-value for the significance test: ${ }^{* * *} p<0.01,{ }^{* *} p<0.05,{ }^{*} p<0.1$.

Source: Author's own study.

The second research hypothesis was verified using Models 4 to 6 . The results of estimations using the GMM system are presented in Table 4. The value of Statistics J in models for economic growth also takes the expected amount. Based on the significance of coefficients standing by the variable of corruption for Model 4, it is possible to confirm the second research hypothesis. In addition, Model 4 has a higher coefficient of determination than Model 6, which has a linear relationship between corruption and economic growth. Characters for coefficients standing by the variable of corruption in Model 4 indicate that the relationship between corruption and economic growth takes the shape of a parabola with arms facing downward. Thus, in this case, it is possible to estimate the maximum of a function, which is at 4.6 points on the scaled corruption indicator. The maximum of a function is close to the maximum corruption rate, which means that the state is free from corruption. The investment rate and population growth take similar values as in other studies (e.g. Cieślik \& Goczek, 2018, p. 329).

Table 4. Models for economic growth

\begin{tabular}{|c|c|c|c|}
\hline & Model 4 & Model 5 & Model 6 \\
\hline Constant & $\begin{array}{c}-23.25692 \\
(* *)\end{array}$ & $\begin{array}{c}-18.27890 \\
(*)\end{array}$ & $\begin{array}{c}11.60616 \\
(* * *)\end{array}$ \\
\hline Corruption & $\begin{array}{c}7.565927 \\
(* *)\end{array}$ & -4.100192 & $\begin{array}{c}0.602555 \\
(* * *)\end{array}$ \\
\hline Corruption $^{\wedge} 2$ & $\begin{array}{c}-0.821988 \\
(*)\end{array}$ & - & - \\
\hline Log(Corruption) & - & $\begin{array}{c}19.37117 \\
(* *)\end{array}$ & - \\
\hline $\log (\mathrm{GDP}) t-1$ & 1.982415 & 2.342360 & $\begin{array}{c}-2.815299 \\
(* * *)\end{array}$ \\
\hline Investment rate & $\begin{array}{c}0.332927 \\
(* * *)\end{array}$ & $\begin{array}{c}0.335250 \\
(* * *)\end{array}$ & $\begin{array}{c}0.288961 \\
(* * *)\end{array}$ \\
\hline Population growth & $\begin{array}{c}-1.427036 \\
(* * *)\end{array}$ & $\begin{array}{c}-1.393709 \\
(* * *)\end{array}$ & $\begin{array}{c}-0.423261 \\
(*)\end{array}$ \\
\hline $\mathrm{R}^{\wedge} 2$ & 0.771970 & 0.771706 & 0.688484 \\
\hline Statistics J & 0.0000 & 0.0000 & 0.0000 \\
\hline
\end{tabular}

Note: $p$-value for the significance test: ${ }^{* *} p<0.01,{ }^{* *} p<0.05,{ }^{*} p<0.1$.

Source: Author's own study. 
Models explaining economic growth require further refinement in terms of additional explanatory variables, because the coefficient of determination is not very high in their case, and $\log (\mathrm{GDP}) t-1$ (which explains the degree of convergence of economies) does not show the desired values (a negative coefficient) for Models 4 and 5 .

\section{Discussion}

Based on the empirical study in this work, it is possible to show that the relationship between corruption and innovation is non-linear. According to the research mentioned above, this relationship takes the shape of a parabola with arms pointing up. This means that the increase in freedom from corruption for the analysed countries will be associated with a growing increase in innovation. This relationship in the literature was also studied by Anokhin and Schulze (2009, p. 472). However, in their research, the relationship between corruption and the measure of innovation took the shape of a parabola with arms facing down. According to Models 1 and 2, an increase in the corruption rate (a decrease of corruption in the economy) leads to greater and greater innovation. This shows that countries should strive to limit corruption as much as possible. By reducing corruption, citizens will be encouraged to register their innovative solutions (the measure of innovation will increase).

Studies on the relationship between corruption and economic growth confirmed the research hypothesis of a non-linear relationship. Méndez and Sepúlveda (2006, pp. 82-98) obtained comparable results for economic growth models with the variable of corruption introduced through the square function. However, Anokhin and Schulze (2009, p. 472) also found a relationship between corruption and economic growth in the shape of a parabola, though, with arms pointing up. According to Model 4 , it is possible to indicate the maximum of a function of economic growth for the variable of corruption. The maximum of this function accounts for the level of 4.6 of the corruption index. This means that the highest economic growth is achieved by countries with such level of corruption of the country. Therefore, countries with a very low level of corruption benefit the most in terms of economic growth. Similar to the models explaining innovation, the model for economic growth shows that states should aim to limit corruption to the maximum level of function for Model 4. A certain low level of corruption is beneficial for an economy in terms of economic growth. This may be because of cultural reasons for corruption (factors difficult to change) that prevent its complete removal. This shows why rich countries such as Germany and France still maintain a low level of corruption, which has not changed significantly in recent decades. 


\section{Conclusions}

The article deals with the relationship between corruption and innovation and corruption and economic growth. The hypotheses about a non-linear relationship between these variables were confirmed in the empirical study. There were particularly interesting conclusions for the research on the impact of corruption on economic growth, where it was possible to calculate the maximum of a function of economic growth in terms of the value of corruption. One result suggests that a low level of corruption may be beneficial for an economy. At the same time, too much corruption hampers economic growth. This situation is well defined by Dzhumashev (2014, p. 212): "the growth rate of a corrupt economy cannot exceed the growth rate of a non-corrupt economy, even if corruption may enhance growth under certain conditions". Just such a low level is achieved by rich European countries. These results were explained by cultural conditions of corruption, which are difficult to change because they result from the habits of the population and some resistance to choosing legal ways to settle the matter. Further reduction of corruption in countries with a low level of it might not have any effect, despite investing enormous funds. These conclusions are significant indicators of the need to manage the level of corruption in the state. Therefore, they are a valuable tool for decision-makers as they try to optimise economic growth.

\section{References}

Aghion, P., Akcigit, U., Cagé, J., \& Kerr, W. (2016). Taxation, corruption, and growth. European Economic Review, 86. doi:10.1016/j.euroecorev.2016.01.012

Ahmad, E., Ullah, M., \& Arfeen, M. (2012). Does corruption affect economic growth? Latin American Journal of Economics, 49(2). doi:10.2307/41959246

Anokhin, S., \& Schulze, W. (2009). Entrepreneurship, innovation, and corruption. Journal of Business Venturing, 24(5). doi:10.1016/j.jbusvent.2008.06.001

Cieślik, A., \& Goczek, Ł. (2015). On the evolution of corruption patterns in the post-communist countries. Equilibrium, 10(1). doi:0.12775/EQUIL.2015.002

Cieślik, A., \& Goczek, Ł. (2018). Control of corruption, international investment, and economic growth. Evidence from panel data. World Development, 103. doi:10.1016/j.worlddev.2017.10.028

Cuervo-Cazurra, A. (2006). Who cares about corruption? Journal of International Business Studies, 37(6). doi:10.1057/palgrave.jibs.8400223

Drury, C., Krieckhaus, J., \& Lusztig, M. (2006). Corruption, democracy, and economic growth. International Political Science Review, 27(2). doi:10.1177/0192512106061423

Dzhumashev, R. (2014). Corruption and growth: The role of governance, public spending, and economic development. Economic Modelling, 37. doi:10.1016/j.econmod.2013.11.007

Jain, P., Kuvvet, E., \& Pagano, M. (2017). Corruption's impact on foreign portfolio investment. International Business Review, 26(1). doi:10.1016/j.ibusrev.2016.05.004

Lau, K., Yang, S., Zhang, Z., \& Leung, V. (2015). Determinants of innovative activities: Evidence from Europe and Central Asia region. The Singapore Economic Review, 60(1). doi:10.1142/S0217590815500046 
Pobrane z czasopisma Annales H - Oeconomia http://oeconomia.annales.umcs.pl

Data: 26/04/2023 11:47:23

THE IMPACT OF CORRUPTION ON ECONOMIC GROWTH AND INNOVATION IN AN ECONOMY...

Méndez, F., \& Sepúlveda, F. (2006). Corruption, growth and political regimes: Cross country evidence. European Journal of Political Economy, 22(1). doi:10.1016/j.ejpoleco.2005.04.005

Méon, G., \& Sekkat, K. (2005). Does corruption grease or sand the wheels of growth? Public Choice, 122(1-2). doi:10.1007/s11127-005-3988-0

Mo, P. (2001). Corruption and economic growth. Journal of Comparative Economics, 29, 66-79. doi:10.1006/jcec.2000.1703

Nelson, R., \& Pack, H. (1999). The Asian miracle and modern growth theory. The Economic Journal, 109(457). doi:10.1111/1468-0297.00455

O'Toole, C. M., \& Tarp, F. (2014). Corruption and the efficiency of capital investment in developing countries. Journal of International Development, 26(5), 567-597. doi:10.1002/jid.2997

Shera, A., Dosti, B., \& Grabova, P. (2014). Corruption impact on economic growth: An empirical analysis. Journal of Economic Development, Management, IT, Finance and Marketing, 6(2).

Pastusiak, R. (2012). Wpływ innowacji na dynamikę wzrostu gospodarczego w modelowaniu ekonomicznym na przykładzie specjalnych stref ekonomicznych. Acta Universitatis Lodziensis, 266.

Pope, J. (1999). Rzetelność zycia publicznego. Warszawa: Instytut Spraw Publicznych.

Wright, A., \& Craigwell, R. (2013). Economic growth and corruption in developing economies: Evidence from linear and non-linear panel causality tests. Journal of Business, Finance and Economics in Emerging Economies, 8(2). 